DOI 10.14746/ssp.2014.1.7

\author{
Violetta JULKOWSKA
}

Uniwersytet im. Adama Mickiewicza w Poznaniu

\title{
Naukowa synteza historii politycznej wobec komercjalizacji rynku wydawniczego
}

K siążki naukowe pisane przez historyków mają grono stałych czytelników, ale rzadko mogą liczyć na masowego odbiorcę. W sytuacji gdy dawne zasady dystrybucji prac naukowych ulegają poważnym zmianom związanym z komercjalizacją rynku wydawniczego pojawia się pytanie o dalsze losy tego typu prac oraz nowe warunki ich obecności na rynku księgarskim. Paradoksalnie bowiem rynek komercyjny, który stwarza potencjalne szanse na sukces czytelniczy, może wpłynąć na podniesienie sprzedaży, ale nie bez postawienia określonych wymagań, których z kolei nie mogą lekceważyć autorzy prac naukowych.

Poczytność określonego typu książek, zaliczanych w rankingach wydawców do bestsellerów głównie dzięki wynikom sprzedaży, analizowana jest wnikliwie przez znawców rynków komercyjnych. Z analiz tych wyłania się ogólny mechanizm powstawania bestsellerów. Zatem pytanie o to, czy naukowa książka historyczna może odnieść sukces w warunkach wolnego rynku jest pytaniem złożonym i wymagającym zastanowienia się nad tym jakie wymagania powinna spełniać książka naukowa, aby zostać bestsellerem, a także nad tym co wyznacza granicę tym wymaganiom z punktu widzenia metod badań i interpretacji wyników.

Różne problemy i wyzwania, przed jakimi stają autorzy tekstów naukowych oraz potencjalne szanse i zagrożenia dla ich autonomii badawczej pojawiają się bowiem nieuchronnie w chwili wyjścia poza osobny obszar dystrybucji, dotąd zarezerwowany dla funkcjonowania prac naukowych. Z drugiej strony strategie stosowane wobec czytelników przez wydawnictwa komercyjne w celu zwiększenia sprzedaży książek, stanowią silną pokusę, na którą coraz częściej przystają autorzy prac naukowych, świadomie kierując swoje kroki na tę ziemię nieznaną.

Analiza i refleksja skupiona będzie na fenomenie naukowych książek historycznych, które przez masowych czytelników uznane zostały za warte czytania, stając się już przed kilkunastu laty swoistymi bestsellerami historycznymi. Ich analiza prowadzona będzie pod kątem charakte- 
rystyki cech właściwym książkom bestsellerowym, które wynikają z oczekiwania wydawców komercyjnych i zazwyczaj formułowane są pod adresem książek nienaukowych.

Pozostałe przykłady, przywołane sporadycznie, pozwolą dokonać namysłu nad problemem nowych możliwości komunikacyjnych, jakie starają się stosować obecnie autorzy tekstów specjalistycznych, nie tyle jednak w poszukiwaniu sposobu popularyzacji swoich prac, ile raczej w reakcji na mechanizmy produkcji i promocji właściwe dla rynku odbiorcy masowego (Bourdieu, 2007, s. 335 i n.).

\section{Wskaźniki „bestsellerowości” na rynku komercyjnym}

Wskazanie głównych kryteriów bestsellera jako swoistego fenomenu na rynku księgarskim i czytelniczym jest stosunkowo proste. W kręgu anglosaskim na listę bestsellerów trafia się na podstawie kryterium mierzonego liczbami bezwzględnymi, ponieważ jedynym wymiernym wyznacznikiem popularności autora jest ilość sprzedanych egzemplarzy, podawana osobno $\mathrm{w}$ kategorii fiction (literatura powieściowa różnego typu) i non-fiction (literatura faktu) (Czubaj, 2005, s. 36). Kryterium to w odniesieniu do niskich nakładów prac naukowych jest względne, ale nie tak bezużyteczne jakby się mogło z razu zdawać. Przykłady książek komercyjnych wydawanych w milionach lub setkach tysięcy egzemplarzy, są pouczające w tym sensie, że wskazują na istotę problemu rynku wydawniczego, którym - bez względu na rodzaj książki - pozostaje ponadprzeciętne zainteresowanie, jakie wśród czytelników musi budzić książka, jeśli ma ambicję stania się bestsellerem.

Innym ważnym wskaźnikiem „bestsellerowości” jest potencjalna moc oddziaływania nazwiska pisarza. Jest ona wypadkową nie tylko rzeczywistego zainteresowania publikacją, ale również towarzyszącego jej wy siłku marketingowego, czynionego przez wydawnictwo dla wypromowania autora na danym rynku czytelniczym. W przypadku książki naukowej nie jest to zabiegiem zbyt częstym, ale wydaje się coraz bardziej niezbędnym. Nazwisko autora, do którego czytelnicy nabrali zaufania jest dla wydawcy gwarantem wysokich nakładów, kolejnych wznowień, ale i większej skuteczności akcji promocyjnych, także w przypadku nowych tytułów. Nawet w sytuacji gdy nie wszystkie prace cieszą się równie dużym zainteresowaniem czytelników, gwarancja nazwiska pozwala przetrwać nawet chwilowy kryzys, spowodowany spadkiem popularności. 
Dodatkowym kryterium, zazwyczaj lokalnym, które nie odwołuje się wprost do praw rynku i jako takie jest raczej nieprzewidywalne, jest moda na określony styl pisarstwa. Jest to kryterium bardziej złożone, jako że bazuje na zmiennych upodobaniach czytelników i jest najczęściej funkcją perswazyjności i niepowtarzalności stylu autorskiego. Ów styl stając się znakiem rozpoznawczym, z oczywistych względów nie może zostać powtórzony przez ewentualnych naśladowców nawet wówczas, gdyby został skutecznie skategoryzowany lub zoperacjonalizowany. Jedynym znanym mi historycznym przykładem udanej inspiracji modnym i wysoko przez czytelników ocenianym stylem pisarstwa było twórcze zaadaptowanie modelu literackiej narracji historycznej Waltera Scotta nie tylko przez innych europejskich pisarzy, ale również przez spora grupę historyków, co miało miejsce w I połowie XIX wieku (Julkowska, 2010, s. 238-250).

Po określeniu wyjściowych kryteriów dla książki-bestsellera pora na postawienie pytania o typy książek historycznych, które przyniosły w ostatnich kilkudziesięciu latach popularność ich autorom i w konsekwencji utrwaliły ich nazwiska na rynku wydawniczym. Odpowiedź na tak postawione pytanie wymaga dodatkowego uwzględnienia cezury chronologicznej, która przypada na przełom XX i XXI wieku. W tym czasie bowiem lista stałych warunków, jakie powinien spełniać bestseller została rozszerzona o bezwzględnie respektowane wymogi marketingowo-komercyjne. O ile wcześniej liczyły się określone upodobania tematyczne i literackie czytelników, kształtowane poprzez ich uczestnictwo w kulturze i tylko częściowo podlegające sterowaniu w ramach krytyki literackiej bądź fachowej, to komercjalizacja działalności wydawniczej znacząco zmieniła tę sytuację. Formułowanie wstępnych wymagań pod adresem autorów rozpoczyna się jeszcze zanim powstanie dzieło i obejmuje zarówno potencjalnie oczekiwania ze strony czytelników, jak i wydawnictw, w wielu przypadkach potrzeby czytelników bywają sztucznie wywoływane.

Podsumowując: książkę spełniającą warunki bestsellera powinny wyjściowo wyróżniać określone cechy oraz podjęte przez wydawnictwo działania wspomagające popularność:

- gatunek pisarstwa akceptowany przez czytelników,

- sprawny warsztat pisarski,

- ocena uznanych recenzentów,

- globalna promocja podjęta przez wydawnictwo,

- opieka menedżersko-marketingowa agencji/agenta. 
Tak więc współczesną tendencją rozwojową komercyjnego rynku wydawniczego, dostrzegalną w każdym z wymienionych warunków, jest dążenie do profesjonalizacji i komercjalizacji na wszystkich poziomach od momentu podjęcia pracy przez autora, aż po działania promocyjne wydawnictwa i agencji reprezentującej autora.

Mimo tej wstępnej diagnozy sądzę, że twórcza praca autora tekstu nad kształtem przekazu i sposobem komunikacji z czytelnikiem nadal pozostaje zadaniem kluczowym oraz wypróbowaną drogą do sukcesu, także w przypadku książki naukowej.

\section{Ulubione przez czytelników gatunki historiograficzne}

Spełnianie przez książkę oczekiwań związanych z wyborem preferowanego przez czytelników gatunku wypowiedzi jako skutecznego sposobu zwrócenia na siebie uwagi, każe zastanowić się nad komunikacyjnymi skutkami owych preferencji. Poszukując przykładów prac o tematyce historycznej, które cieszą się niesłabnącym zainteresowaniem można wskazać szczególnie ulubione przez publiczność czytającą gatunki. Ich wspólną cechą charakterystyczną jest budząca żywe zainteresowanie forma narracji, która sprawia, że problematyka historyczna uznawana przez czytelników za trudną, przekazywana jest w sposób atrakcyjny. Należy do tych gatunków esej historyczny, biografia historyczna oraz autorska synteza historyczna, rzadko monografia historyczna. Każda $\mathrm{z}$ wymienionych form wykorzystuje w różnym stopniu swoją specyfikę narracyjną oraz związek z opowiadaniem jako sposobem przekazu i wyjaśniania. Można zaobserwować prawidłowość polegającą na tym, że autorzy prac naukowych, którzy starają się w niekonwencjonalny, a zarazem przemawiający do wyobraźni czytelnika sposób przedstawić poruszany problem, cieszą się podobnym do pisarzy zainteresowaniem, co potencjalnie otwiera ich pracom drogę na listy bestsellerów. Wystarczy wspomnieć o powodzeniu książek Normana Davies'a, które spośród innych prac historycznych wyróżnia właśnie forma przekazu, czego przykładem jest nowatorska Europa. Jej dwuznaczny podtytuł: Rozprawa historyka z historiq, odnosi się między innymi do zrealizowanego przez autora zamiaru wyjścia poza konwencjonalne granice akademickich argumentów i analiz, także na poziomie konstrukcji narracji (Davies, 1998, s. 13). Davies dla wzbogacenia i urozmaicenia przebiegu narracji chronologicznej, nieco nużącej dla czytelnika ze względu na ogrom ma- 
teriału historycznego, zastosował dodatkowo dwie perspektywy narracyjne. Pierwszą było ujęcie mikrohistoryczne (tzw. „kapsułki” w liczbie 301, to węższe zagadnienia i tematy przecinające główny nurt chronologiczny narracji, wprowadzające dodatkowe odniesienia i uzupełnienia, także o nowe metody, dyscypliny i dziedziny, czasem ukazujące poboczne nurty historiografii), natomiast drugą ujęcie makrohistoryczne (tzw. „migawki”, czyli panoramy czasowo-przestrzenne, pełniące funkcję rekapitulacyjna). Obie z punktu widzenia czytelnika były w momencie wydania książki świeżym i niekonwencjonalnym pomysłem na urozmaicenie żmudnej lektury poprzez podwójną zmianę optyki historycznej. To co wydawać się mogło zwykłym uatrakcyjnieniem przebiegu tekstu narracji było $\mathrm{w}$ rzeczywistości połączeniem dwóch typów budowania narracji, przynależących do odmiennych sposobów ujmowania przeszłości w ramach szkół historiograficznych. W efekcie skonstruowana została narracja pośrednia łącząca cechy narracji nieklasycznej modernistycznej (panoramy) oraz nieklasycznej pomodernistycznej (kapsułki) (Wrzosek, 2010; Domańska, 2005). Całość obudowana została ogromna ilością dodatkowych materiałów, ale w sposób przypominający łatwo dostępne i przejrzyste bazy danych. Promocja książki w Polsce przypadła na czas rozbudzania aspiracji europejskich w społeczeństwie oraz wdrażania europejskiego wymiaru w edukacji. Atrakcyjność przekazu oraz moment wybrany na promocję książki zwielokrotniły efekt zainteresowania się tą pozycją przez szeroką publiczność czytająca, a nie tylko przez osoby deklarujące zainteresowania historyczne.

Wracając do spraw gatunków preferowanych przez czytelników, można zaobserwować duże możliwości innowacyjne, jakie stwarza esej historyczny. Jego hybrydyczna forma z pogranicza literatury, historii i filozofii sprzyja grze komunikacyjnej z czytelnikiem. Esej jest jednak formą wymagającą w odbiorze określonego potencjału kulturowego, dlatego siegają po niego czytelnicy poszukujący inspiracji intelektualnej a nie tylko informacji. Esej otwiera autorowi możliwość formułowania refleksji świadomie, obarczonej ryzykiem niepewności i niekompletności, pomaga w przedstawieniu wiedzy nie tyle pewnej, ile dopiero wyważanej w toku dyskusji. Eseistyka podobna jest więc literaturze w tym, że sprzyja wyrażaniu problemów, które nie znajdują swojej formy w dyskursie naukowym, a co dopiero rozgrywa się w sferze wyobraźni, w przestrzeni niedopowiedzeń i pytań, które chwilowo nie znajdują jednoznacznych odpowiedzi. Esej budując swoistą relację między autorem a czytelnikiem, wymaga bardziej zindywidualizowanego i zsubiektywi- 
zowanego kontaktu aniżeli rozprawa naukowa (Julkowska, 2011, s. 63 i n.; Julkowska, 2012, s. 11-31). Jego forma zapewnia piszącemu komfort swobodnego kształtowania językowej strony wypowiedzi, aż do zabiegów artystycznych włącznie, co sprzyja odrzuceniu krępujących rygorów i ram wypowiedzi oficjalnej lub autorytatywnej. Esej historyczny, zgodnie z cechami gatunku, podejmuje próbę nie tylko nowego rozumowania, ale także innowacyjnej formy wypowiedzi. Oryginalny przekaz eseju idzie zazwyczaj w parze ze sposobem budowania refleksji opartej na paradoksie, metaforze lub wieloaspektowym widzeniu poruszanego problemu. Tak zarysowane możliwości, ale i wymagania gatunkowe eseju, wysoko zawieszają poprzeczkę wszystkim stronom procesu komunikacji, dlatego skutecznie zmniejszają grono zainteresowanych tą formą pisarstwa.

Współczesny esej historyczny kojarzony bywa z nazwiskiem Pawła Jasienicy, lecz trudno ze względów formalnych zaliczyć jego prace do eseistyki historycznej, rozumianej tak jak została ona zdefiniowana wyżej. Wymagania te spełniają przykłady ambitnych esejów naukowych wydawanych współcześnie przez oficyny związane z ośrodkami naukowymi ${ }^{1}$. Wbrew tym warunkom podzielam przekonanie, że esej to droga do sukcesu, a wynika ono z faktu silnie utrwalonej w wysokiej kulturze literackiej XX wieku obecności eseju o tematyce historycznej, którą poruszali między innymi: Jerzy Stempowski, Józef Czapski, Melchior Wańkowicz, Gustaw Herning-Grudziński, Czesław Miłosz i Zbigniew Herbert (Heck, 2003, s. 5-25). Lektura ich prac ukształtowała kilka pokoleń czytelników, przygotowując do obcowania z książką wymagająca samodzielnej refleksji. Prace wymienionych autorów, mimo iż należą do ulubionej przez czytelników kategorii non-fiction, nie spełniają akceptowanych przez środowiska akademickie standardów pracy naukowej ze względu na dominację cech literackich nad wymogami warsztatu krytycznego. Naukowy esej historyczny i historiograficzny, należący jeszcze na początku XX wieku do stałego repertuaru gatunków przez historyków uprawianych i cenionych, także w formie wypowiedzi popularyzującej historię, ustępuje współcześnie miejsca innym formom i sposobom wypowiedzi np. hipertekstowi (Vandendorpe, 2008, s. 116-122).

Również chętnie czytanym gatunkiem piśmiennictwa historycznego pozostaje nadal biografia historyczna, pisana najczęściej przez autorów

1 Por. Seria „Communicare” wydawana przez UW, redaktor serii Andrzej Mencwel. 
przygotowanych do analizy materiału źródłowego, która w odróżnieniu od autobiografii, wspomnień i pamiętników, spełnia warunki związane z wymogami historycznego warsztatu krytycznego. Znane od lat wielkie serie biograficzne wydawnictw: PWN oraz Ossolineum, zarówno tytuły wznawiane, jak i nowe pozycje, cieszą się niesłabnącym zainteresowaniem czytelników. Ta wyraźnie ukierunkowana, a przy tym od lat nie ulegająca zmianom preferencja czytelnicza, znajduje wyjaśnienie w tym, że biografia historyczna jako gatunek historiograficzny odpowiada na stale obecne - co istotne również w kulturze masowej - zainteresowanie opowieścią o losach znanych ludzi. Opowieść ta konstruowana jest według określonej liczby kulturowo utrwalonych schematów narracyjnych, wypracowanych od czasów starożytnych (Kasperowicz, Wolicka, 2005, s. 365; Zalejko, 1988, s. 37-55). W tym wypadku zadanie postawione przed autorami biografii polega na konieczności poszukiwania nowego pomysłu na ujęcie materiału biograficznego, innego niż te wypracowane już przez kulturę, a przy tym nieobecnego w historiografii. Nowego podejścia wymagają przykładowo: losy więźniów obozów koncentracyjnych, historia ofiar różnego typu działań opresyjnych czy też opowieści przedstawicieli grup społecznych zagrożonych utratą ciagłości historycznej lub tożsamości kulturowej. Takie podejście wypracowywane jest od pewnego czasu w ramach nowych perspektyw badawczych, które proponują między innymi: studia poświęcone pamięci, a także studia postkolonialne i genderowe. W tych obszarach można zaobserwować przykłady niekonwencjonalnych i zarazem adekwatnych w stosunku do pozyskanych źródeł sposobów perswazyjnego komunikowania się z czytelnikiem (Filipkowski, 2010). Przykładem takich właśnie starań jest niedawno wydana i już okrzyknięta światowym bestsellerem książka Petera Englunda Piękno i smutek wojny, będąca skuteczną próbą łączenia wymiaru historii powszechnej i historii prywatnej (Englund, 2011). Autor - znany historyk, sekretarz Akademii Szwedzkiej, przedstawia losy dwudziestu różnych osób, z różną intensywnością i skalą przeżyć uwikłanych w czasy pierwszej wojny światowej, wykorzystując przy tym z możliwości, jakie stwarza połączenie konwencji kroniki ze źródłem historii prywatnej. Kronika stałą się ramą porządkującą chronologię wydarzeń w latach 1914-1918, którą autor wypełnił krótkimi epizodami z życia swoich niefikcyjnych, wymienionych z imienia i nazwiska bohaterów. Ich losy historyk opisał w ponad dwustu historiach utkanych z materii źródeł historii prywatnej, należących do bohaterów tych wydarzeń. Połączenie erudycji historycznej z opanowaniem warsztatu literac- 
kiego pozwoliło na udramatyzowanie, a zarazem personalizację wydarzeń dokonaną w stylu wielkiej literatury powieściowej. Autor spełnił tym samym wszystkie warunki wyjściowe, aby zapewnić sobie zainteresowanie czytelników, reszty dokonała dobra organizacja akcji promocyjnej (w Polsce tuż przed Świętami Bożego Narodzenia 2011).

Obok eseju i prac biograficznych kolejnym gatunkiem, który stwarza szerokie spektrum działań i pole do potencjalnych poszukiwań jest autorska synteza historyczna.

\section{Fenomen autorskiej syntezy historycznej}

Dobrze napisane, autorskie syntezy historyczne budzą niezmiennie żywe zainteresowanie czytelników i gwałtowne reakcje środowiska historyków? Dzieje się tak z różnych powodów, także dlatego, że ich konstrukcja nawiązuje do zadomowionych w naszym kręgu kultury upodobań do epickich opowieści o przeszłości.

Aby to stwierdzić nie wystarczy dokonać merytorycznej oceny syntez, lecz należy przyjrzeć się ich koncepcji, ujawniającej intencję autora i zamysł interpretacyjny, dostrzec sposób konstrukcji narracji oraz moc perswazyjną syntezy, które są łącznym efektem wielu zabiegów autora. Zatem musimy spojrzeć na konstrukcję syntezy z perspektywy wyznaczonej przez analizę sposobu komunikowania się autora z czytelnikami.

W swoich spostrzeżeniach odwołam się do analizy trzech wybranych autorskich syntez historycznych, powstałych w tym samym czasie, choć w różnych kontekstach historycznych. Sa to prace autorstwa: Paula Johnsona Historia świata od 1917 roku (Johnson, 1987)², Normana Davies'a Boże igrzysko. Historia Polski (Davis, 2004) ${ }^{3}$ oraz Andrzeja Alberta (Wojciecha Roszkowskiego) Najnowsza historia Polski 1918-1980 (Albert) ${ }^{4}$.

2 Tłumaczenie polskie przygotowane na podstawie przekładu przygotowanego przez zespół tłumaczy Wydawnictwa „Wers” z Wrocławia.

3 Pierwsze wydanie w wersji oryginalnej angielskiej ukazało się w latach 1981-1982 w Oxfordzie, pierwsze polskie wydanie miało miejsce w 1987 roku. Książka była kilkakrotnie wznawiana, a także decyzją MEN została wpisana do zestawu książek pomocniczych do nauczania historii na poziomie szkoły średniej W zestawie nr 124/92.

4 Andrzej Albert (właściwie Wojciech Roszkowski), Najnowsza historia Polski 1918-1980 (pierwotnie książka funkcjonowała w drugim obiegu, wydawana była kilkakrotnie w latach 1978-1984 przez oficyny podziemne „Krag”, „Pokolenie”, 
Każda z nich spełniała kryteria bestsellera naukowego i za taki w swoim czasie uchodziła.

Syntezy Johnsona i Davise'a reprezentują odmienne style komunikowania, nieznane w oficjalnym obiegu naukowym czytelnikowi polskiemu przed 1980 rokiem. Obie syntezy cechuje wybitnie autorskie i oryginalne podejście do oceny dziejów: u Johnsona dotyczy ona historii świata w XX wieku (w tym również spraw polskich) natomiast u Davise'a przebiegu i oceny całej historii Polski. Obie prace zostały udostępnione polskim czytelnikom w przełomowym momencie historycznym, co dodatkowo wpłynęło na ich popularność.

Z kolei synteza Alberta, stała się bestsellerem w sposób nietypowy i paradoksalny z punktu widzenia mechanizmów wolnorynkowych funkcjonujących w państwach demokratycznych Europy Zachodniej. Książka była wydawana trzykrotnie przez oficyny niezależne i funkcjonowała w drugim obiegu, a więc w stosunkowo małych nakładach i nielegalnie, począwszy od 1978 roku. Mimo cenzury szybko zyskała sławę książki uzupełniającej „białe plamy” w polskiej historii i najnowszej. Należała do nielicznych publikacji, dzięki którym możliwe stało się przełamanie monopolu komunistycznej interpretacji dziejów najnowszych, obowiązującej w polskich podręcznikach do historii XX wieku. Synteza Alberta wprowadzała do narracji odmienną, wolnościową perspektywę, uzyskaną dzięki częściowemu dowartościowaniu okresu międzywojennego oraz nurtu niepodległościowego z czasów II wojny światowej. Po 1990 roku, a więc już w okresie Polski niepodległej, książka Alberta odpowiednio uzupełniona stała się jednym z pierwszych oficjalnych podręczników tzw. „maturalnych”. Dzięki zaufaniu społecznemu jaki wzbudzała i ugruntowanej popularności zapoczątkowała serię podręczników spółki autorskiej: Anna Radziwiłł i Jerzy Roszkowski, niezwykle cenionych za rzetelny przekaz, chociaż pisanych tradycyjnie, a więc według zasad klasycznej historii zdarzeniowej.

Uogólniając swoje spostrzeżenia mogę stwierdzić, że tym co w pierwszej kolejności decyduje o powodzeniu każdej syntezy autorskiej, tak jak zadecydowało o popularności wymienionych prac, jest zręczne połączenie wiedzy ogólnej i specjalistycznej autora z jego umiejętnościami warsztatowymi i literackimi, idące $\mathrm{w}$ parze $\mathrm{z}$ odwagą formułowania

a następnie londyńską oficynę niezależną „Polonia”. W roku 1991 w wersji rozszerzonej książka ukazała się jako podręcznik do szkoły średniej już pod właściwym nazwiskiem autora, znanego dotąd pod pseudonimem Albert). 
własnych poglądów na dzieje, a przy tym w niebanalnym stylu komunikowanych. Autorytet autora, nawet wówczas gdy wygłasza on oceny kontrowersyjne, ma z punktu widzenia czytelnika i rankingu książek pretendujących do roli bestsellera znaczenie kluczowe, dużo większe aniżeli ukryty za redaktorem zespół autorski, składający się z wybitnych specjalistów.

Decyduje walor całościowego ujęcia i przy tym spójna koncepcja, które niejako zwalnia czytelnika z konieczności samodzielnych i żmudnych studiów opartych na pracach monograficznych i opracowaniach. Synteza tworzy - w zamian za zaufanie do interpretacji autorskiej - ogólny pogląd na dzieje, porządkujący wiedzę trudną do samodzielnego ogarnięcia przez laików. Praca interpretacyjna wykonana przez historyka wyposaża odbiorcę w gotową wizję dziejów, podsuwa mu argumentację i sprawia - to najbardziej przez czytelników ceniona cecha - że w określonym zakresie problemowym czytelnik staje się kompetentnym komentatorem przeszłości i teraźniejszości. Synteza umożliwia bowiem spojrzenie z unikalnej perspektywy, którą można porównać do punktu obserwacyjnego umieszczonego ponad wydarzeniami, a przy tym ogarniającego ich całość w sposób zdystansowany.

Kolejnym mocnym atutem historycznej syntezy autorskiej jest skomplikowany mechanizm konstrukcji narracji historycznej, ukryty przed oczyma czytelników, ale jednak obecny i odczuwalny, jako sposób porządkowania i wyjaśniania dziejów. Mechanizm ten pogłębia wrażenie rozumienia i ogarniania całości, chociaż nie pozwala naiwnym, czyli niekrytycznym odbiorcom narracji, na zorientowanie się w skali działań perswazyjnych, jakiej są poddawani, a w skrajnych przypadkach nawet autorskiej manipulacji, której ulegają dzięki zręcznej konstrukcji całościowego obrazu przeszłości.

Paradoks syntez historycznych - których atrakcyjność przekazu, odbierana bywa jako umiejętność literacka - polega na tym, że właściwa praca historyka nad konstrukcją obrazu przeszłości pozostaje ukryta.

Budowanie tego typu narracji historycznej, narracji jako opowieści, ma jeszcze jeden walor, a mianowicie nadaje jej charakter alternatywny w stosunku do typowych prac naukowych i z tego powodu zbliża autorskie syntezy historyczne do granicy stylu prac o charakterze popularyzującym. Z drugiej strony niekonwencjonalność tego typu prac historycznych, oryginalność, a często nawet kontrowersyjność głoszonych poglądów i ocen sprawia, że są one odbierane przez czytelników jako alternatywne wobec oficjalnych podręczników. Poczytność przywołanych syntez spra- 
wiła, że stawały się one podręcznikami (przypadek książki Alberta i Johnsona) lub materiałami zalecanymi jako pomocnicze i uzupełniające (synteza Davies’a), przy czym decyzja władz oświatowych zapadła post factum i sankcjonowała stan faktyczny, a więc uprzednio docenioną przez czytelników atrakcyjność tych prac.

Podsumowując fenomen autorskiej syntezy historycznej jako specyficznego typu komunikacji z czytelnikiem, można wskazać następujące kluczowe atuty tego gatunku:

- autorytet historyka, akceptowany przez czytelnika,

- perspektywę narracyjna, obejmującą całościowe obrazy historyczne,

- gotowy pogląd i ocenę dziejów, przyjmowaną jako własna bez dodatkowych studiów,

- mechanizm dziejów ukryty za konstrukcją narracji,

- alternatywny charakter narracji historycznej.

\section{Pytania i konkluzje}

Przykład bestsellerowej książki Davisa Boże igrzysko dowodzi, że wskazane charakterystyczne cechy autorskich syntez historycznych budzą w środowisku samych historyków mieszane uczucia, a także głosy krytyczne. Środowisko historyków nawet jeśli pozytywnie ocenia autorskie syntezy, to jednak sceptycznie podchodzi do możliwości przygotowania przez jedną osobę takiej pracy, zwłaszcza gdy obejmuje ona szeroki zakres materiału historycznego. Sens owej „twórczej zdrady” polega właśnie na tym, że historyk starając się zachować zasady warsztatu naukowego czerpie z bazy erudycyjnej, jaką stanowią dla niego wcześniej powstałe prace monograficzne innych autorów, ale nadając nowe sensy interpretacyjne całościowemu obrazowi przeszłości, zgodnie z własną autorską koncepcją. Tym sposobem autor syntezy świadomie oddziałuje na czytelnika masowego, ku któremu kieruje wszystkie swoje starania perswazyjne i konstrukcyjne, jakie czyni wokół narracji ${ }^{5}$ (Escarpit,

${ }^{5}$ Określenie pochodzi z rozważań z zakresu socjologii komunikacji opisanych przez Escarpita, gdzie mechanizm „twórczej zdrady” odnosi się do komunikacji literackiej i polega na odwołaniu się do cechy dysponowalności jaką posiada dzieło literackie, które zdradza sensy zgodne z autorską intencją oraz pierwszych czytelników (recepcja w kontekście macierzystym) z odbiorcami usytuowanymi w innych przestrzeniach historycznych, społecznych, kulturowych. 
1976, s. 235). Takie odczytanie gatunkowej cechy syntezy historycznej potwierdzają słowa Davies'a ze wstępu do Bożego igrzyska: „Wkładem historyka w historię nie jest jednak wyłącznie wiedza o przedmiocie. Perspektywa, proporcje, zaangażowanie emocjonalne - jednym słowem to, co artyści i muzycy nazywają »tonacją《 - wszystko to odgrywa swoją rolę" (Davis, 2004, s. 14). Syntezy autorskie same stają się również materiałem wyjściowym o dużej „dysponowalności”, a więc również podatnym na „twórczą zdradę”, którą można rozumieć jako zdolność do generowania nowych znaczeń poza własnym kontekstem i czasem powstania.

Czas na pytanie o to kiedy „twórcza zdrada”, rozumiana jako zdolność inspirującego generowania nowych znaczeń wyczerpuje się lub dewaluuje.

Masowe środki komunikowania narzucając styl i formę debaty o przeszłości narzucają również historykom nowe reguły gry. Historycy świadomi utraty swojej uprzywilejowanej dotąd pozycji zagwarantowanej dla akademickiej historiografii starają się nie pozostawać obojętnymi wobec nowych sposobów docierania do szerokiego kręgu odbiorców jakie stwarzają media. Jedną ze strategii kompensujących utratę dawnej pozycji bywa przenoszenie stylu komunikowania się z odbiorcą charakterystycznego dla masmediów na grunt profesjonalnie tworzonej narracji historycznej. Nowe standardy komunikowania pomagają w dotarciu do masowego czytelnika, ale niebezpiecznie zbliżają w ten sposób tworzone teksty do granicy pisarstwa historycznego. Mój sceptycyzm wobec takich zabiegów prowadzi do kolejnego pytania o to, czy społeczny charakter misji, jaką mają do spełnienia naukowe książki historyczne, uzasadnia stosowanie perswazyjnych środków przekazu na gruncie historiografii akademickiej. W rzeczywistości jest to pytanie o granice tego typu działań.

Historycy starając się zmieniać sposób docierania z problematyką historyczną do masowego odbiorcy nie tylko poszukują kontaktu z wydawnictwami komercyjnymi czy masowymi mediami, ale także sami wkraczają na nowy obszar, często mało rozpoznany i bywa, że zmuszeni są do przyjęcia reguł obowiązujących na tym obszarze. W nowej sytuacji zmianie ulega nie tylko styl narracji i emocje wyrażane na poziomie języka, ale także standardy badań, a wraz z nimi wymagania warsztatowe pracy historycznej, zasady interpretacji wyników badań i etyki zawodowej. „Panowanie mediów oznacza, że pozbawiają one inne pola autonomii nie przez bezpośredni nacisk, ale przez to, że proponują czy 
raczej stopniowo obligują uczestników pola intelektualnego lub politycznego, do przyjęcie innych, specyficznych dla mikroświata mediów, wzorów kariery i nagród. Media rozszerzają tym samym swoje wpływy, umożliwiając uczestnikom pola naukowego nową strategię organizowania swojej kariery przez balansowanie pomiędzy dwoma światami" (Jacyno, 2009, s. 19).

Jeśli więc pytamy o granicę pola symbolicznego, możliwą do wskazania dla historycznych prac naukowych, a czynimy to w kontekście oczekiwań komercyjnego wydawcy, to powyższy cytat - będący komentarzem do koncepcji pola Bourdieu - uświadamia nam jej płynność i wynikające stąd zagrożenie.

Osobne pytanie dotyczy dopuszczalnych przez środowiska naukowe działań komercyjnych podejmowanych przez wydawnictwa dla pozyskania czytelnika masowego. W sytuacji zaniku dystynkcji między wydawnictwami naukowymi i komercyjnymi stają się one praktyką coraz częściej stosowaną.

Sądzę, że niebezpieczeństwem dla książki naukowej nie są zabiegi służące jej upowszechnieniu z myślą o akcie lektury tekstu naukowego dokonywanego przez czytelnika masowego, lecz przyjęcie postawy kalkulującej, która objawia się komercjalizacją myślenia autora już na poziomie projektu książki. Komercjalizacja skutkuje ostatecznie dopasowaniem pisanej historii do wymogów nie tyle czytelnika masowego, co raczej masowej konsumpcji. Konsumpcja książek nie jest tożsama z ich lekturą.

\section{Bibliografia}

Albert A. (1991), Najnowsza historia Polski 1918-1980.

Bourdieu P. (2007), Reguty sztuki. Geneza i struktura pola literackiego, Wydawnictwo „Universitas”, Kraków.

Czubaj M. (2005), Kod bestsellera, „Polityka” nr 37.

Davis N. (2004), Boże igrzysko. Historia Polski, Wydawnictwo Znak, Kraków.

Davies N. (1998), Europa. Rozprawa historyka z historiq, Kraków.

Domańska E. (2005), Mikrohistorie: spotkania w międzyświatach, Wydawnictwo Poznańskie, Poznań.

Englund P. (2011), Piękno i smutek wojny. Dwadzieścia niezwyklych losów z czasu światowej pożogi, Wydawnictwo Znak, Kraków. 
Escarpit R. (1976), Literatura a społeczeństwo, przeł. J. Lalewicz, w: Współczesna teoria badań literackich za granica. Antologia, oprac. H. Markiewicz, t. III, Wydawnictwo Literackie, Kraków.

Filipkowski P. (2010), Historia mówiona i wojna. Doświadczenie obozu koncentracyjnego $w$ perspektywie narracji biograficznych, Wydawnictwo Uniwersytetu Wrocławskiego, Wrocław.

Heck D. (2003), Kosmopolityzm i sarmatyzm. Antologia powojennego eseju polskiego, Zakład Narodowy im. Ossolińskich, Wrocław.

Jacyno M. (2009), Przedmowa do polskiego wydania, w: P. Bourdieu, O telewizji. Panowanie dziennikarstwa, Warszawa.

Johnson P. (1989), Historia świata od 1917 roku, Wydawnictwo „Wers” z Wrocławia-Wydawnictwo Polonia, Londyn.

Julkowska V. (2010), Historia dla wyobraźni. Recepcja i interpretacja pisarstwa historycznego Karola Szajnochy, Wydawnictwo Poznańskie, Poznań.

Julkowska V. (2011), Polski esej historyczny w XIX i XX wieku, cz. I: Szkice historyczne Szajnochy i Kubali-narodziny polskiego eseju historycznego, w: Klio Polska. Studia i materiaty z dziejów historiografii polskiej XIX-XX wieku, t. V, red. A. Wierzbicki, Wydawnictwo Neriton, Warszawa.

Julkowska V. (2012), Polski esej historyczny w XIX i XX wieku, cz. II: Funkcje dwudziestowiecznej eseistyki historycznej, w: Klio Polska. Studia i materiaty $z$ dziejów historiografii polskiej XIX-XX wieku, t. VI, red. A. Wierzbicki, Wydawnictwo Neriton, Warszawa.

Kasperowicz R., Wolicka E. (2005), Biografia, historiografia dawniej i dziś. Biografia nowoczesna, nowoczesność biografistyki, Towarzystwo Naukowe Katolickiego Uniwersytetu Lubelskiego, Lublin.

Vandendorpe Ch. (2008), Od papirusu do hipertekstu. Esej o przemianach tekstu i lektury, Wydawnictwo Uniwersytetu Warszawskiego, Warszawa.

Wrzosek W. (2010), Historia - Kultura-Metafora. Powstanie nieklasycznej historiografii, Wydawnictwo Uniwersytetu Wrocławskiego, Wrocław.

Zalejko G. (1988), Biografistyka historyczna - zarys ewolucji gatunku, „Historyka”, t. XVIII.

\section{An academic book on history as a bestseller \\ - an analysis of selected examples}

\section{Summary}

The paper presents the phenomenon of academic books on history that mass readers have deemed to be worth reading, thus making them a kind of history bestsellers, when it is rare for academic books written by historians to enjoy mass 
acclaim. In her analysis, the author emphasizes those features of bestsellers that follow from their publishers' commercial expectations. The analysis concerns the following books, among others: Europa (Europe) and Boże Igrzysko (God's Playground) by Norman Davies, Historia Świata od 1917 roku (A History of the Modern World from 1917 to the 1980s) by Paul Johnson and Historia Polski 1918-1980 (History of Poland from 1918 to 1980) by Andrzej Alber. 
